Селергей Н. В., кандидат історичних наук, доцент, доцент кафедри фбілософбї і суспільних наук Української медичної стоматологічної академії

\title{
ВІДОБРАЖЕННЯ В НОВІТНІЙ ІСТОРІОГРАФІЇ ПЕРЕДУМОВ УКРАЇНСЬКОГО НАЦІОНАЛЬНОГО РУХУ ДРУГОЇ ПОЛОВИНИ ХІХ - ПЕРШОЇ ТРЕТИНИ ХХ СТОЛІТТЯ
}

\begin{abstract}
Анотація. Статтю присвячено аналізу стану висвітлення в новітній українській історіографії передумов піднесення українського національно-культурного відродження у другій половині XIX - першій третині XX століття. На основі цілісного та компаративного підходу до аналізу історії України з'ясовано, що серед передумов історики називають політичні, економічні, соціальні та культурі зміни, які переживали Російська й АвстроУгорська імперії в середині ХІХ століття. Доведено, що, підкреслюючи загальноукраїнський масштаб національного відродження, дослідники все ж розглядають його передумови в територіальному (Наддніпрянщина та західноукраїнські землі) вимірі. Історики наголошують, що стартові позиції національного руху на Наддніпрянщині були значно сильнішими, ніж у Галичині. До його передумов у підросійській Україні дослідники відносять вагомі здобутки в розвитку української мови, культури та літератури, розвиненість суспільно-громадянської думки, яка забезпечила ідейну підготовленість нового етапу національного руху, сукупність соціально-економічних і адміністративно-політичних перетворень, які Російська імперія пережила за підсумками доби «Великих реформ». Натомість серед передумов активізації національного відродження в Галичині історики називають революцію 1848 року, скасування панщини й ухвалення Конституції, інтегрованість регіону в європейські суспільні трансформації, винятковий авторитет і духовно-культурну роль греко-католицького духовенства, інтенсивність та радикальність соціально-економічних змін, активізацію національних рухів угорців, чехів та поляків тощо. Доведено, що, на думку дослідників, ключовою передумовою піднесення національного життя українців була попередня культурна традицію, яка виявилась у першій фазі українського національного відродження. Історики, простежуючи передумови національно-культурного відродження, звертають увагу на поетапність і наступність процесу: слов'янофіли підготували Кирило-Мефодіївське братство, його симпатики, після арештів організаторів, дали поштовх Старій і Молодій громадам, а остання стала ядром Братства тарасівців, члени якого заснували Революційну українську партію з іiі самостійницькою програмою. У Галичині «Руська трійця» започаткувала подібний процес, який продовжився в діяльності осередків «Просвіти» та «Наукового товариства імені Шевченка», розвиткові українського руху в ініціативах народовців, радикалів і «Буковинської трійці», відзначеннях ювілейних дат українських письменників та, нарешті, формуванні української партійно-політичної системи у Східній Галичині (Русько-українська радикальна партія, Українська національно-демократична партія, Українська соціал-демократична партія й інші).
\end{abstract}

Виявлено, що панівною в історіографії є думка про те, що духовно-культурний потенціал першого етапу національного відродження (кінець XVIII - перша половина XIX століття) став соціокультурною основою для його динамічної еволюції, набуття ним нових інституційно-організаційних форм та подальшої політизації.

Ключові слова: українське національно-культурне відродження, історичні передумови, новітня українська історіографія, соціально-економічні зміни, політизація суспільного життя, Наддніпрянщина, західноукраїнські землі, націєтворчі процеси.

Постановка проблеми. Початок третього тисячоліття позначився піднесенням українського національно-етнічного, суспільно-політичного, громадянського та духовно-культурного життя, яке із здобуттям Україною державної незалежності набуло нових імпульсів та започаткувало потрійну трансформацію українського суспільства. На думку істориків (Я. Ісаєвич [1], Г. Касьянов [2], В. Сарбей [3]), сучасний етап національного руху є свідченням безперервності, поетапності та наступності національно-культурного відродження, яке українські землі переживають із кінця XVIII ст. Широкий масштаб і національний характер українського відродження відіграли виняткову державотворчу роль, адже його зміст забезпечив формування та «соціалізацію» національної ідеї, «масовізацію» національної свідомості, отже, розвиток націєтворчих процесів [2]. 3-поміж передумов сучасного етапу національного відродження Я. Ісаєвич називав здобутки Української Народної Республіки, суспільну роботу діячів Української Радянської Сціалістичної Республіки (далі - УРСР), які намагалися розширювати її політичну автономію та базу для розвитку культури, форми культурницької діяльності, що були можливі за умов тоталітаризму, внесок учасників визвольного Руху часів Другої світової війни, геройську боротьбу «дисидентів» тощо [1, с. 142]. Науково й історично правильне визначення передумов і чинників національного відродження дає змогу не лише розуміти його сучасний зміст і характер, але й прогнозувати напрями та динаміку розвитку. Саме тому розгляд стану дослідженості в новітньому історичному пізнанні передумов піднесення українського національного відродження у другій половині XIX ст., на наш погляд, виправданий науково-евристичними та практичними перспективами.

Аналіз останніх досліджень і публікацій. У новітній історичній науці аналізові XIX ст. присвячено значний масив наукових праць. Історики вивчали суспільно-політичний контекст, розглядали сутність, окреслювали цивілізаційний вимір 
українського національно-культурного відродження, яке становило основний зміст вітчизняного історичного процесу імперської доби. У студіях з історії українського XIX ст. було представлено й окремі історіографічні аспекти. 3-поміж великої кількості наукових досліджень найбільший внесок у вивчення нового етапу українського національного відродження у другій половині XIX ст. зробили такі історики, як: В. Венгерська [4], В. Верига [5], І. Гирич [6], Я. Грицак [7], С. Єкельчик [8], Л. Зашкільняк [9], Я. Калакура [10], Г. Касьянов [2], 3. Когут [11], М. Кугутяк [12], В. Масненко [13], М. Мудрий [14], А. Павко [15], С. Плохій [16], Ю. Присяжнюк [17], О. Реєнт [18-19], О. Рубльов [19], В. Сарбей [3], О. Сухий [20], Д. Чорний [21], Н. Шип [22], Р. Шпорлюк [23], В. Яремчук [24] та інші. Вагомий історіографічний наратив представлено в рецензіях на монографії зазначених істориків, які дозволяють грунтовніше та ширше розглянути запропоновані дослідниками історичні висновки [25-28]. Водночас цілісної історіографічної синтези, завданням якої був аналіз новітніх історичних досліджень про передумови піднесення національного руху у другій половині XIX ст., нам не відомо, що підтверджує гносеологічну актуальність цієї статті.

Мета статті - концептуалізувати новітній історіографічний дискурс про передумови нової хвилі українського національно-культурного відродження у другій половині XIX ст., простежити відображення в наукових працях істориків таких його ознак, як поетапність і наступність, розглянути регіональні особистості, характер і динаміку розвитку українського національного руху.

Виклад основного матеріалу дослідження. У новітній історіографії важно знайти заперечення думці про те, що українське національно-культурне відродження XIX - першої третини XX ст. не було історичною випадковістю. Дослідники, аналізуючи його зміст, динаміку та регіональні особливості, стверджують, що український вимір піднесення національного руху та розвитку націєтворчих процесів органічно вписується в європейські національно-визвольні процеси модерної доби, т. зв. «емансипацію» бездержавних народів, які втратили або ж взагалі не мали власних політичних еліт, їхня соціальна структура обмежувалася селянством, а культура - народною культурою. Незалежно від того, прихильником пріоритету якої концепції українського «довгого століття» є дослідник (національне відродження чи творення нації), перед ним неминуче постають питання про передумови, суспільно-політичний та соціокультурний контекст розвитку національного руху, об'єктивні результати якого стали основою новітньої української державності. У зв'язку з тим, що історики, підкреслюючи загальноукраїнський масштаб національного відродження [18], усе ж розглядають його в територіальному (Наддніпрянщина та західноукраїнські землі) вимірі, то й історіографія передумов нового етапу українського національного руху у другій половині XIX ст. може бути систематизованою відповідно.

Осмислюючи чинники піднесення українського руху у другій половині XIX ст, низка істориків зазначають, що цей період у контексті його загальної еволюції умовно був другою стадією. Історіографії відомо приблизно десяток підходів до аналізу хронології українського національного відродження, зокрема концепції вітчизняних дослідників (Я. Грицак, І. Колесник, О. Пріцак, В. Сарбей) та підходи істориків еміграційної школи (М. Грох, І. Лисяк-Рудницький, П.-Р. Магочій, Р. Шпорлюк).
Водночас більшість із цих підходів так чи інакше синхронізуються із загальновизнаною в західній історіографії класифікацією стадій національного руху: перша - наукова, коли інтелігенція починала пошуки контурів національної свідомості; друга - культурницька, або період патріотичного відродження, коли історія стає засобом творення культурного простору; третя - політична, коли культурна окремішність шукає свого політичного виразу [29, с. 159; 23, с. 11]. Відповідно до такого розуміння динаміки національного відродження, період другої половини XIX ст. був підготовлений попереднім культурницьким піднесенням, а його основний зміст визначався політизацією суспільного життя й інституційно-організаційного оформлення національного руху.

Дотримуючись пріоритетів цілісного та компаративістського підходу до історії України, ми схиляємося до думки про доцільність розглянути історіографію національно-культурного відродження з акцентом на особливості цього процесу на Наддніпрянщині та західноукраїнських землях, зважаючи на те, що ці регіони перебували у складі різних імперій, що були на різних етапах модернізації суспільства. Такий підхід все ще залишається панівним в українській історіографії, хоча маємо низку досліджень порівняльного характеру (В. Венгерська, А. Галушка, Я. Дашкевич, О. Донік, О. Реєнт, О. Сухий та інші).

Розглядаючи передумови й особливості українського національного руху в Наддніпрянській Україні, його нового піднесення у другій половині XIX ст., історики наголошують, що його стартові позиції були значно сильнішими, ніж у Галичині. До передумов другої фази національного відродження дослідники відносять вагомі здобутки в розвитку української мови, культури, літератури; розвиненість суспільно-громадянської думки, яка забезпечила ідейну підготовленість нового етапу національного руху; сукупність соціально-економічних і адміністративно-політичних перетворень, які Російська імперія пережила за підсумками доби «Великих реформ» [4; 18].

Однією із ключових передумов піднесення національного руху на Наддніпрянщині у другій половині XIX ст. В. Сарбей, O. Реєнт та інші називають його певні успіхи на попередньому етапі, який розпочався наприкінці XVIII ст. як культурницький. Відомо, що основним змістом тогочасного культурного піднесення було збирання українського фольклору та розвиток народної культури, зацікавлення українською мовою, літературою та історією рідного краю. Значно посилила перший етап національного відродження літературна творчість зачинателя нової української мови І. Котляревського, а спадщина Т. Шевченка «<.. > справила величезний вплив на розвиток національного руху завдяки поєднанню національного та соціального елементів» [30, с. 105]. Зміст першого етапу національного відродження був представлений появою «Історії Русів» та виданням «Енеїди», літературною творчістю та видавничою діяльністю О. Бодянського, Є. Гребінки, П. Гулака-Артемовського, М. Костомарова, П. Куліша, М. Максимовича, І. Срезневського й інших, підготовкою та виданням історичних синтез тощо. Знаковою постаттю в цьому процесі всі дослідники називають Тараса Шевченка, з огляду на його особливу роль у розгортанні нового етапу українського національного руху.

Усталеною в історіографії є думка, що із творчістю Т. Шевченка у структурі українського руху викристалізовується ідея національного та соціального визволення, його здатність до критично-сатиричного сприйняття дійсності. Філософія цього 
мислителя збагатила український інтелектуальний простір парадигмою україноцентризму, обгрунтуванням ідеї самобутності українського історичного процесу, його безперервності та наступності. Вона актуалізувала у свідомості та ментальній сутності українців любов до рідного краю, красу українського села як носія традиційної хліборобської культури та менталітету, героїку козацького лицарства нації. Навіть більше, сучасні дослідники підкреслюють, що національні ідеї Т. Шевченка стали проривом до системного сприйняття світу, насамперед українського, без імперської ідеї «руского міра» [31, с. 318-319].

У сукупності передумов розвитку національного руху на Наддніпрянщині важливе місце дослідники відводять підготовці його ідейної основи, ключову роль у чому історики відводять діяльності Кирило-Мефодіївського братства. Цінність його ініціатив полягала в тому, що кирило-мефодіївці виступали за послідовність соціальних і національних перетворень [32, с. 7]. Крім того, у їхній суспільно-політичній програмі вагоме місце належало гуманістичним ідеям. Історики підкреслюють, що кирило-мефодіївці як справжні послідовники християнських гуманістичних ідей піднесли до рівня програмних положень принцип побудови управління, законодавства та права власності на засадах християнського вчення. Члени товариства турбувалися про те, щоб домогтися ліквідації розбіжностей між слов'янськими племенами, особливо в конфесійних питаннях [33, с. 73].

Цікавим уважаємо й виокремлення дослідниками складників кирило-мефодіївської ідеології, яка обумовила формування ідейних засад національного відродження у другій половині XIX ст. До них відносять: національний (слов'янська й українська ідеї, панславізм, слов'янофільство й українофільство); державно-політичний і міжнародний (повалення іноземного панування, проголошення незалежності слов'янських країн і створення республіканської федерації, месіанська роль України у слов'янському світі); соціальний (скасування кріпацтва і станів, забезпечення рівності громадян перед законом); економічний (ліквідація поміщицького землеволодіння і наділення селян землею за принципом справедливості, вільне промислове виробництво і торгівля, здійснення природного права людей на задоволення життєвих потреб); культурницький (загальна безоплатна освіта для простого народу, розвиток національної культури, запровадження української мови в усіх сферах життя); релігійний (зміцнення авторитету християнської церкви, припинення релігійних незгод православних і католиків, віротерпимість і толерантність духовенства та віруючих, духовне і морально-етичне виховання людей за християнськими євангельськими догматами та заповідями) складники [34, с. 14].

Водночас в історіографії поширеною є дискусія про те, чи ідеї всеслов'янської єдності не послабили самостійницькі позиції національного руху? Відомо, що в українському середовищі Наддніпрянщини впродовж усього національного відродження поширювалися дві панівні концепції щодо майбутнього України: автономізм і самостійництво. Ідейні основи першого значно послаблювали національний характер українського руху, хоча, на думку деяких учених, можливо, були найбільш реалістичною стратегією розвитку українства в умовах імперського колоніалізму.

Важливою передумовою розвитку національного руху був його селянський сегмент 3 антикріпосницьким спрямуванням, що прискорив соціально-економічні зміни, передусім скасування кріпацтва та початок промислового перевороту. Їхні наслідки помітно змінили соціальний склад населення, частково лібералізували суспільно-політичне життя та дали поштовх формуванню інтелігенції. Я. Грицак звертав увагу на кризовий аспект розвитку інтелігенції, яка не змогла знайти повноцінного застосування своїх інтелектуальних сил у громадському та державному житті. На його думку, інтелігенція була переконаною в тому, що потрібно покласти край соціальній несправедливості, відсталості й іншим непривабливим рисам російського самодержавства, але їй бракувало соціальної сили для здійснення своїх ідеалів. Багато інтелігентів бачили вихід у створенні опозиційних - народницьких, ліберальних, марксистських рухів, спроможних трансформувати й модернізувати Російську імперію [7, с. 62].

Наявні праці з історії піднесення українського національного руху на західноукраїнських землях засвідчують дещо інші його передумови. Зміст, динаміка та характер нової фази українського національного руху на західноукраїнських землях у другій половині XIX ст. зумовлювалися відмінною від імперії Романових політичною та соціокультурною ситуацією в тогочасній Австро-Угорській імперії, іiі специфікою. Ключовою подією, яка визначила зміст суспільно-політичних і соціальноекономічних передумов розвитку національного відродження, стала революція 1848 р., яка виявилася «<...> підготовчим етапом національного руху та сприяла розгортанню динамічного політичного руху галицьких українців. Потужними рушійними силами тут були звільнення селян, організуюча роль греко-католицької церкви i, до певної міри, політика Відня, що використовувала «русинів» у боротьбі з польським домінуванням уГаличині» [30, с. 106].

Історики схиляються до думки, що важливою передумовою розвитку національного відродження галицьких українців у другій половині XIX ст. стало скасування панщини й ухвалення Конституції. Ці події позначилися на соціальній структурі західноукраїнського населення, у якому селянство становило більшу частину, отже, звільнення його від панщини було першим кроком для зростання соціальної активності. Водночас деякі дослідники скептично оцінювали впливовість реформ для розвитку національного відродженні в регіоні. Так, С. Пахолків зазначав, що селянська реформа 1848 р. не змінила ситуації на селі, не заклала основ ані для загального економічного розвитку, ані для розвитку селянства. Громадянських прав, рівних 3 іншими прошарками населення, селяни не отримали. Вони й надалі залишалися в економічній залежності від великих землевласників [35, с. 110].

Якщо соціально-економічні ефекти революції 1848 p. викликають дискусії в середовищі істориків, то ії суспільно-політична ресурсність однозначно оцінюється позитивно. Ідеться про те, що революцією було створено умови для політичної активності українців. Історики позитивно оцінюють виникнення національних організацій, очолюваних Головною Руською Радою, появу української преси («Зоря Галицька»), вибори до парламенту та діяльність у ньому українських депутатів, роботу делегатів-українців у празькому Слов'янському з’їзді, розроблення національно-політичної програми, у якій було проголошено єдність усіх українців і висунуто гасло поділу «коронного краю Галичини» із метою подолання переваги поляків у населеній переважно українцями Східній Галичині тощо [30, с. 106]. Можна погодитися 3 думкою П.-Р. Магочія 
про те, що «<... значення революційного 1848 р. для українців Австрійської імперії важко переоцінити. < ..> українці в Австрійській Галичині й, меншою мірою, в угорському Закарпатті досягли значного прогресу в національному житті. У Галичині українці заснували політичні і культурні організації, газети та інші видання, а також мали власних представників у національному парламенті. Найбільша соціальна група селянство - була звільнена з кріпацтва, а її представники почали брати участь у політичному житті» [36, с. 400].

3-поміж передумов національного піднесення в західноукраїнських землях історики також називають інтегрованість регіону в європейські суспільні трансформації, винятковий авторитет і духовно-культурну роль греко-католицького духовенства, інтенсивність та радикальність соціально-економічних змін, активізацію національних рухів угорців, чехів та поляків тощо. Аналізуючи передумови національного відродження в Галичині, С. Пахолків звертає увагу, зокрема, на посилення позицій греко-католицького кліру, який відіграв вирішальну роль у наданні культурницькому піднесенню суспільного та політичного забарвлення. Учений зауважував: «Греко-католицьке духовенство ідеально виконувало вимоги до провідників національного руху. 3 одного боку, воно не було асимільоване та зберегло свою етнічну самобутність, з іншого залишалося єдиною елітою тогочасного українства Галичини. Його патріотизм мав конфесійне підгрунтя. Греко-католицьке віросповідання виявилося надійною та простою характерною ознакою в самоідентифікації галицьких українців» [35, с. 69].

Крім суспільно-політичних і соціально-економічних передумов активізації українського руху, виняткове значення мали соціокультурні чинники. Перший етап національного відродження в Галичині був представлений широкою духовно-релігійною та культурно-просвітницькою діяльністю товариства греко-католицьких священиків, суспільними ініціативами «Руської трійці», виданням першого літературного твору розмовною українською мовою в Галичині «Русалка Дністрова» тощо. Під час першої стадії національного відродження виняткова роль належала греко-католицьким священикам. В. Сарбей підкреслював, що саме в їхньому середовищі з'явилися перші пробудники національно-культурного відродження у Східній Галичині та на Закарпатті, які стали суб'єктами національного піднесення у другій половині XIX ст. [3, с. 58].

Дослідники звертають увагу на те, що порівняно з Наддніпрянщиною перша фаза національного відродження в західноукраїнських землях розпочалася кількома десятками років пізніше. Водночас такі «свіжі» культурні основи дали необхідні імпульси для динамічного розвитку національного руху у другій половині XIX ст. У регіоні значно швидше, ніж у підросійській Україні, відбувалися процеси політизації національного руху. На думку П.-Р. Магочія, якщо до Першої світової війни в Наддніпрянській Україні національний рух пройшов лише збиральницьку стадію, то в Галичині було закладено необхідні основи національного життя - історична ідеологія, мова, література, культурні організації, освіта, релігія і політика, що дало змогу галицьким українцям пройти культурницьку та політичну стадії національного поступу [36, с. 369, 442].

Висновки. Загалом історики спільні в думці, що нова хвиля українського руху та національно-культурного у другій половині XIX - на початку XX ст. була закономірним результатом об'єктивного розвитку суспільно-історичного процесу всіх українських земель, хоча й не однаковою мірою. До його передумов відносять політичні, економічні, соціальні та культурні зміни, які переживали імперії в середині XIX ст. Водночас дослідники однією із ключових передумов усе ж називають попередню культурну традицію, яка виявила себе в першій фазі українського національного відродження. Історики, простежуючи передумови національно-культурного відродження, звертають увагу на поетапність і наступність цього процесу: слов'янофіли підготували Кирило-Мефодіївське братство, його симпатики, після арештів організаторів, дали поштовх Старій i Молодій громадам, а остання стала ядром Братства тарасівців, члени якого заснували Революційну українську партію з іiі самостійницькою програмою. У Галичині «Руська трійця» започаткувала подібний процес, який продовжився в діяльності осередків «Просвіти» та «Наукового товариства імені Шевченка», розвиткові українського руху в ініціативах народовців, радикалів та «Буковинської трійці», відзначеннях ювілейних дат українських письменників та, нарешті, формуванні української партійно-політичної системи у Східній Галичині (Русько-українська радикальна партія, Українська національно-демократична партія, Українська соціал-демократична партія й інші). Духовно-культурний потенціал культурницького етапу національного відродження став соціокультурною основою для його динамічної еволюції, набуття ним нових інституційно-організаційних форм (культурно-освітні організації, наукові товариства, економічна кооперація) та подальшої політизації. Цікавою для перспективних досліджень, на наш погляд, $є$ історіографія політизації та самоорганізації українського національного руху наприкінці XIX ст., яка була логічним і закономірним результатом його культурного піднесення.

Лimepamypa:
1. Iсаєвич Я. Наші три відродження - не лише здобутки, а й втрати. Сучасність. 1998. № 12 (452). С. 136-143.

2. Касьянов Г. Теорії нації та націоналізму. Київ : Либідь, 1999. 352 c.

3. Сарбей В. Національне відродження України. Україна крізь віки : у 15 т. Т. 9 / за заг. ред. В. Смолія ; НАН України, Ін-т археології, Ін-т історії України. Київ : Альтернативи, 1996. 336 с.

4. Венгерська В. Українські проекти та процеси націотворення в імперіях Романових та Габсбургів (кінець XVIII - початок XX ст.). Житомир : Вид-во ПП Євенок О.О., 2013. 456 с.

5. Верига В. Нариси з історії України (кінець XVIII - початок XX ст.). Львів : Світ, 1996. 447 с.

6. Гирич I. Українські інтелектуали і політична окремішність (середина XIX - початок XX ст.) / відп. ред. О. Рубльов. Київ : Укр. письменник, 2014. 496 c.

7. Грицак Я. Нарис історії України : формування модерної української нації XIX-XX ст. : навчальний посібник. Київ : Генеза, $1996.360 \mathrm{c}$

8. Єкельчик С. Українофіли : Світ українських патріотів другої половини ХІХ століття. Київ : КІС, 2010. 272 с.

9. Зашкільняк Л. Галичина на ментальних мапах українців XIX початку XX століття. Україна - Свропа - Світ : міжнародний збірник наукових праць. Серія «Історія, міжнародні відносини». 2012. Вип. 10. С. 94-105.

10. Калакура Я., Рафальський О., Юрій М. Ф. Українська культура : цивілізаційний вибір. Київ : ІПіЕНД ім. І.Ф. Кураса НАН України, $2015.496 \mathrm{c}$

11. Когут 3. Коріння ідентичності. Студії з ранньомодерної та модерної історії України. Київ : Критика, 2004. 352 с.

12. Кугутяк М. Галичина. Сторінки історії. Нарис суспільно-політичного руху (XIX ст. - 1939). Івано-Франківськ, 1993. 200 с. 
13. Масненко В. Історична думка та націєтворення в Україні (кінець XIX - перша третина XX ст.). Київ ; Черкаси : Відлуння-Плюс, $2001.439 \mathrm{c}$

14. Час народів. Історія України XIX ст. : навчальний посібник / О. Аркуша та ін. ; за ред. М. Мудрого. Львів : ЛНУ імені Івана Франка, 2016. 408 с.

15. Павко А. Україна в імперську добу (Рец. на кн. : Реєнт О. Україна в імперську добу (XIX - початок XX ст.). Київ : Інститут історії України НАН України, 2003. 340 с.). Віче. 2003. № 7. С. 77-78.

16. Плохій С. Козацький міф. Історія та націєтворення в епоху імперій. Авториз. пер. з англ. М. Климчука. Київ : Laurus, 2013. 440 с.

17. Присяжнюк Ю. Українське селянство Наддніпрянської України : соціоментальна історія другої половини XIX - початку XX ст. : монографія. Черкаси : Вертикаль, 2007. 638 с.

18. Реєнт О. Україна в імперську добу (XIX - початок XX ст.). Київ : Інститут історії України НАН України, 2003. 340 с.

19. Рубльов О., Реєнт О. Українські визвольні змагання 1917-1921 pp. Київ : Альтернативи, 1999. 320 с

20. Сухий О. Галичина : між Сходом і Заходом. Нариси історії XIX початку XX ст. 2-е вид., доп. Львів : ЛНУ імені Івана Франка, 1999. $226 \mathrm{c}$

21. Чорний Д. Історія Слобідської України : підручник. Харків : ХНУ імені В.Н. Каразіна, 2016. 264 с.

22. Шип Н. Интеллигенция на Украине (XIX в.). Историко-социологический очерк. Киев : Наукова думка, 1991. 172 с.

23. Шпорлюк Р. Формування модерних націй : Україна - Росія - Польща. Пер. $з$ англ. Г. Касьянова та ін. Київ : Дух і Літера, 2013. 552 с.

24. Яремчук В. Українська багатопартійність Наддніпрянської і Західної України : монографія. Київ : ІПІЕНД, 2012. 503 с.

25. Гуржій О. Дослідження про Україну в складі імперій (Рец. на кн. : Реєнт О. Україна в імперську добу (XIX - початок XX ст.). Київ : Інститут історії України НАН України, 2003. 340 с.). Воєнна істоpiя. 2002. № № 5-6. С. 13-136.

26. Кугутяк М., Монолатій І. Вагомий внесок в історіографію історії України нової доби. (Рец. на кн. : Реєнт О. Україна в імперську добу (XIX - початок XX ст.). Київ : Інститут історії України НАН України, 2003. 340 с.). Історія Галичини. 2003. № 9. С. 198-202.

27. Мельничук О. (Рец. на кн. : Венгерська В. Українські проекти та процеси націотворення в імперіях Романових та Габсбургів (кінець XVIII - початок XX ст.). Житомир : Вид-во ПП Євенок О.О., 2013. 456 с.). Наукові записки Віннииького державного педагогічного університету імені Михайла Кочюбинського. Серія «Історія» збірник наукових праць. Вінниця, 2013. Вип. 21. С. 296-298.

28. Ясь О. (Рец. на кн. : Гирич І. Українські інтелектуали і політична окремішність (середина XIX - початок XX ст.) / відп. ред. О. Рубльов. Київ : Укр. письменник, 2014. 496 с.). Украӥнський історичний журнал. 2014. № 5. С. 209-213.

29. Касьянов Г. Українська інтелігенція на рубежі XIX-XX століть : соціально-політичний портрет. Київ : Либідь, 1993. 176 с.

30. Каппелер А. Національний рух українців у Росії та Галичині: спроба порівняння. Україна: культурна спадщина, національна свідомість, держсавність : збірник наукових праць. Київ : Наукова, думка, 1992. Вип. 1. С. 104-119.

31. Калакура Я., Рафальський О., Юрій М. Ментальний вимір української цивілізації. Київ : Генеза, 2017. 560 с.

32. Голобуцький О., Кулик В. Український політичний рух на Наддніпрянщині : кінець XIX-початок XX ст. Київ : Смолоскип, 1996. 124 с.

33. Щербак Н. Європейський вплив на процеси українського відродження XIX ст. Украӥнознавчий альманах. 2014. Вип. 11. С. 70-73.

34. Панафідін I. Концепт «українське національне відродження» у дослідженнях вітчизняних істориків 90-х рp. XX ст. Наукові записки Тернопільського національного педагогічного університету імені Володимира Гнатюка. Серія «Історія». 2017. Вип. 2. С. $9-17$
35. Пахолків С. Українська інтелігенція у Габсбурзькій Галичині : освічена верства й емансипація нації. Львів : ЛА «Піраміда», 2014. 612 c

36. Магочій П.-Р. Україна. Історія ії земель та народів. Пер. з англ. Е. Гийдель та ін. ; ред. укр. вид. Л. Ільченко ; відп. ред. В. Падяк. Ужгород : Вид-во В. Падяка, 2012. 794 с

Semerhei N. Reflection of prerequisites of Ukrainian national movement of the second half of the XIXth - the first third of the XXth century in modern historiography

Summary. The article is devoted to the analysis of the study of prerequisites for the rise of Ukrainian national and cultural revival in the second half of the XIXth - the first third of the XXth century in the modern Ukrainian historiography. Based on a holistic and comparative approach to the analysis of Ukrainian history, it has been found that among these prerequisites historians single out political, economic, social and cultural changes that the Russian and Austro-Hungarian Empires experienced in the middle of the XIXth century. It has been proved that emphasizing the nationwide scale of national revival, the researchers are still considering its preconditions in the territorial (Naddnipryanschina and Western Ukraine) dimension. Historians point out that the starting points of the national movement in Naddnipryanschina were much stronger than in Halychyna. To these prerequisites in Russian Ukraine researchers include significant achievements in the development of the Ukrainian language, culture and literature, the development of socio-civic thought, which provided the ideological readiness of a new stage of the national movement, a set of socio-economic, administrative and political transformations that the Russian Empire underwent during the age of the Great Reforms. Instead, among the prerequisites for the revitalization of national revival in Halychyna, historians mention the revolution of 1848, the abolition of serfdom and the adoption of the Constitution, integration of the region in European social transformations, significant spiritual and cultural role of the Greek Catholic clergy, the intensity and social activism of Hungarians, Czechs and Poles, etc. It has been proved that according to the researchers the key prerequisite for raising the national life of the Ukrainians was the previous cultural tradition, which manifested itself in the first phase of Ukrainian national revival. Historians, tracing the prerequisites for national and cultural revival, draw attention to the stages and succession of the process: Slavophiles has prepared the ground for Brotherhood of Saints Cyril and Methodius, its supporters, after arrest of the organizers, gave impetus to the Old and Young communities, and the latter became the nucleus of Tarasivtsi Brotherhood, which members founded the Revolutionary Ukrainian Party with its independent program. A similar process in Halychyna was initiated by the Russian Trinity, which continued in the activities of "Enlightenment" and "Shevchenko Scientific Society", the development of the Ukrainian movement initiated by the Narodovtsi, Radicals and Bukovyna Trinity, the commemoration of the anniversary dates of Ukrainian writers and finally, the formation of Ukrainian political party system in Eastern Halychyna. It has been revealed that the dominant in historiography is the idea that spiritual and cultural potential of the first stage of national revival (the end of the XVIIIth - the first half of the XIXth century) became a socio-cultural basis for its dynamic evolution, formation of new institutional and organizational forms and further politicization.

Key words: Ukrainian national and cultural revival, historical prerequisites, modern Ukrainian historiography, socio-economic changes, politicization of social life, Naddnipryanschina, Western Ukrainian lands, national processes. 